\title{
PENINGKATAN KETERAMPILAN BAHASA INGGRIS PRAKTIS BERORIENTASI KERJA BAGI PESERTA KEJAR PAKET C DI KELURAHAN TANJUNG KARANG KOTA MATARAM - NUSA TENGGARA BARAT
}

\author{
Etika Ariyani
}

Pendidikan Bahasa Inggris, Universitas Muhammadiyah Mataram, ikachevy06@gmail.com

\begin{abstract}
ABSTRAK
Abstrak: Pelatihan ini bertujuan untuk membekali peserta program Kejar Paket C dengan keterampilan bahasa inggris praktis yang sesuai dengan kebutuhan mereka guna meningkatkan peluang memperoleh pekerjaan (jobs oriented). Pelatihan ini difokuskan pada kemampuan menguasai empat keterampilan utama dalam bahasa inggris yaitu keterampilan membaca (reading), menulis (writing), menyimak (listening) dan berbicara (speaking). Peserta pelatihan terdiri atas 25 peserta, pelatihan diselenggarakan selama 10 minggu tatap muka dimana tiap kali pertemuan terselenggara selama 90 menit. Indikator keberhasilan pelatihan ini dinilai dari dua dimensi yaitu dimensi output dan outcome. Hasil dari pelatihan ini dapat meningkatkan keterampilan dan motivasi peserta program Kejar Paket C secara signifikan dimana pencapaian peningkatan keterampilan bahasa inggris peserta meningkat menjadi $75 \%$.

Kata Kunci: peningkatan, keterampilan bahasa inggris, pelatihan.

Abstract: This training aims to improve English ability of Kejar Paket C participants based on their needs, this training can improve their chances to get jobs easily. This training focused to mastering four major skills in English such as speaking, writing, listening and reading. This training consists of 25 participants and held for ten weeks, every session consist of 90 minutes. Successful indicator program evaluate from output which assessed from learning materials achievement, the participants comprehension and ability to speak English fluently. Outcome assessed from the participants ability to mastering English orally and writtenly; the comparation of pre and post test. The result of this training can improve the participants ability and motivation. The participants achievement improve significantly until $75 \%$.
\end{abstract}

Keywords: improvement, English skills, training.

Riwayat Artikel: Diterima: 18 Desember 2017, Disetujui: 20 Januari 2018 


\section{A. PENDAHULUAN}

Perkembangan ilmu pengetahuan dan teknologi tak dibendung lagi dan terus berkembang pesat. Pada era globalisasi dan informasi ini, bangsa Indonesia dituntut mampu bersaing dengan bangsa-bangsa lain di seluruh dunia dalam berbagai sector kehidupan. Untuk dapat beradaptasi dengan tatanan kehidupan yang semakin maju, peningkatan sumber daya manusia harus diutamakan. Semakin maju suatu bangsa, maka peningkatan sumber daya manusianya harus diutamakan. Seperti kita ketahui dengan mulai diberlakukannya Masyarakat Ekonomi ASEAN (MEA) pada akhir tahun 2015, maka persaingan antar Negara khususnya antar Negara-negara ASEAN akan menjadi semakin dinamis dan kompetitif. Hal tersebut tidak hanya terjadi di bidang ekonomi akan tetapi era pasar bebas ini menuntut semua orang untuk mampu bersaing di segala bidang. Penguasaan ilmu pengetahuan dan teknologi dapat menentukan kemampuan suatu bangsa untuk survive dalam persaingan di era globalisasi ini.

Era pasar bebas saaat ini tentunya akan memberikan peluang besar bagi Indonesia guna meningkatkan eksistensinya di kawasan ASEAN. Masyarakat Ekonomi ASEAN (MEA) tidak hanya membuka arus perdagangan barang dan jasa tetapi juga tenaga kerja professional dalam berbagai bidang. Artinya hal tersebut akan menciptakan terbukanya peluang lapangan kerja baru baik bagi tenaga kerja professional maupun tenaga kerja level menengah ke bawah. Sebenarnya tenaga kerja Indonesia cukup unggul dan mampu bersaing dengan tenaga kerja dari Negara-negara lain namun kendala bahasa menjadi penghambat mereka untuk mendapatkan pekerjaan. Penguasaan bahasa asing khususnya bahasa inggris sangat penting dimana bahasa inggris menjadi bahasa internasional diseluruh dunia. Penguasaan bahasa inggris menjadi kebutuhan utama bagi individu - individu yang ingin bersaing dalam dunia kerja.

Bahasa sangat berperan penting untuk menguasai komunikasi baik dalam basis teknologi maupun dalam berinteraksi secara langsung. Penguasaan bahasa internasional khususnya bahasa inggris menjadi suatu keharusan agar dapat beradaptasi dan mengikuti arus perkembangan global yang semakin maju. Seperti yang kita ketahui bersama bahwa bahasa inggris sangat mendominasi segala aspek kehidupan manusia diseluruh dunia. Penguasaan bahasa inggris dapat menjadi nilai tambah bagi para pencari kerja. Di era MEA ini perlu adanya perubahan pola piker bahwa bahasa inggris menjadi kebutuhan utama bagi para pencari kerja yang tidak bisa ditawar-tawar lagi.

Kelemahan dalam penguasaan bahasa inggris merupakan salah satu penyebab rendahnya sumber daya manusia di Indonesia. Aliansi atau keterasingan manusia dari masyarakat dunia yang semakin maju seakan melanda Negara kita dengan sindrom "gagap bahasa" padahal Indonesia saat ini berada dalam kepungan persaingan global yang begitu masif. Hal inilah yang menjadi penyebab utama perkembangan ilmu pengetahuan dan teknologi di Negara kita berjalan lamban padahal teknologi dan keilmuan modern masa kini berkembang pesat di luar negeri dan bahasa yang paling memungkinkan sebagai "jembatan penghubung" pengetahuan tersebut adalah bahasa inggris. Upaya mewujudkan daya saing pemuda atau generasi muda melalui peningkatan keterampilan bahasa inggris merupakan salah satu langkah konkrit guna mengejar ketertinggalan dan memperkaya pengetahuan melalui akses informasi.

Pendidikan nasional sangat berperan penting bagi pembangunan manusia seutuhnya karena dapat mewujudkan manusia Indonesia yang berakhlak mulia, berkarakter, produktif dan berdaya saing sehingga dapat meningkatkan kemakmuran dan kesejahteraan rakyat. Sistem pendidikan nasional di Indonesia menjamin pemerataan kesempatan memperoleh pendidikan bagi seluruh masyarakat Indonesia. Peningkatan mutu pendidikan serta relevansi dan efisiensi 
manajemen pendidikan guna menghadapi tantangan sesuai dengan tuntutan perubahan kehidupan lokal, nasional dan global sehingga perlu segera dilakukan pembaharuan- pembaharuan dalam bidang pendidikan secara terencana, terarah dan berkesinambungan. Tuntutan akan pemenuhan hak dasar manusia tersebut tidak dapat ditawar-tawar lagi karena hanya dengan penguasaan ilmu pengetahuan dan teknologi kita mampu bersaing di era global. Keinginan untuk meningkatkan pengetahuan, kemampuan dan keterampilan sebagai bekal hidup layak dimiliki oleh seluruh manusia, namun kenyataan yang terjadi di Indonesia saat ini adalah angka putus sekolah yang masih tinggi yang disebabkan oleh tingginya biaya pendidikan dan keterbatasan ekonomi orang tua. Salah satu solusi untuk mengatasi masalah tersebut adalah melalui penyelenggaraan pendidikan kesetaraan sebagai salah satu bagian dari Sistem Pendidikan Nasional.

Nusa Tenggara Barat (NTB) khususnya pulau Lombok merupakan salah satu destinasi wisata yang sangat diminati baik oleh wisatawan lokal maupun mancanegara. Oleh sebab itu peningkatan kemampuan berbahasa inggris sangatlah penting terutama bagi para peserta kejar paket $\mathrm{C}$, penguasaan bahasa asing khususnya bahasa inggris dapat menjadi nilai tambah dan meningkatkan peluang kerja mereka di bursa tenaga kerja. Dengan demikian maka tujuan pelaksanaan pengabdian masyarakat ini adalah guna membantu meningkatkan kemampuan berbahasa inggris peserta kejar paket $\mathrm{C}$ melalui pelatihan bahasa inggris praktis yang sesuai dengan kebutuhan peserta dan berorientasi kerja (job oriented).

\section{B. TINJAUAN PUSTAKA}

\section{Program Kesetaraan Kejar Paket C}

Pendidikan kesetaraan adalah jalur pendidikan nonformal dengan standar kompetensi lulusan (SKL) yang sama dengan sekolah formal. Namun kontens, konteks, metodologi dan pendekatan untuk mencapai standar kompetensi lulusan tersebut lebih memberikan konsep terapan, tematik, induktif yang terkait dengan permasalahan lingkungan dan melatihkan kecakapan hidup yang berorientasi kerja (job oriented). Pendidikan kesetaraan merupakan salah satu program Pendidikan Nasional yang terstruktur dan dinilai. Salah satu program pendidikan kesetaraan adalah Kejar Paket C yang setara dengan Sekolah Menengah Atas (SMA) dalam pendidikan formal dan bertujuan untuk memperluas dan meratakan akses pendidikan. Kriteria peserta didik dalam Kejar Paket C adalah mereka yang telah lulus dari Kejar Paket B atau Sekolah Menengah Pertama (SMP/MTs), tidak mendapatkan pendidikan di sekolah formal karena beberapa factor ( potensi diri, keterbatasan waktu, kondisi ekonomi, hukum dan keyakinan).

Dasar kebijakan Program Kejar Paket adalah Undang-Undang Dasar 1945 Pasal 28b Ayat 1 "setiap orang berhak mengembangkan diri melalui pemenuhan kebutuhan dasarnya, berhak mendapatkan pendidikan dan mendapatkan manfaat dari ilmu pengetahuan dan teknologi, seni dan budaya demi meningkatkan kualitas hidupnya bagi kesejahteraan umat manusia”. Dalam implementasinya diperkuat dengan Undang-Undang Republik Indonesia Nomor 20 tahun 2003 tentang Sistem Pendidikan Nasional Pasal 5 Ayat (1) dan (5) yaitu (1) setiap warga Negara mempunyai hak yang sama untuk memperoleh pendidikan yang bermutu; (5) setiap warga Negara berhak mendapatkan kesempatan meningkatkan pendidikan sepanjang hayat. Setiap peserta didik yang lulus ujian pada Program Kejar Paket C mempunyai eligibitas yang sama dan setara dengan pemegang ijazah pada sekolah-sekolah formal (SD/MI,SMP/MTs, SMA/MA) untuk mendaftar pada satuan pendidikan yang lebih tinggi maupun untuk mencari pekerjaan. Sesuai dengan amanat UndangUndang Dasar 1945, pendidikan nonformal disamakan statusnya dengan 
pendidikan formal. Para peserta yang mengikuti pendidikan kesetaraan adalah mereka yang tidak pernah mendapatkan pendidikan di jalur pendidikan formal, putus sekolah, lulusan atau orang-orang yang masih membutuhkan lebih banyak peningkatan pengetahuan dan keterampilan.

Peraturan yang menjelaskan lebih lanjut mengenai Standar Isi dan Standar Kompetensi Lulusan (SKL) adalah Peraturan Menteri Pendidikan Nasional Republik Indonesia Nomor 23 Tahun 2006 tentang Standar Kompetensi Lulusan (SKL) bagi Satuan Pendidikan Dasar dan Menengah yang menegaskan beberapa point penting berikut yaitu Standar Kompetensi Lulusan Satuan Pendidikan (SKL-SP) dikembangkan berdasarkan tujuan setiap satuan pendidikan yakni Pendidikan Dasar yang meliputi SD/MI/SDLB/Paket A ; SMP/MTs/SMPLB/Paket B bertujuan meletakkan dasar kecerdasan, pengetahuan, kepribadian, akhlak mulia serta keterampilan untuk dapat hidup mandiri dan mengikuti pendidikan lebih lanjut.

\section{Pembelajaran Bahasa Inggris Praktis.}

Bahasa sebagai media komunikasi tentunya menggunakan simbol-simbol dan karakteristik bunyi bahasa itu sendiri. Simbol dan karakteristik masing -masing bahasa itu berbeda-beda antara satu dengan yang lainnya, untuk itu belajar bahasa memerlukan pengetahuan terkait dengan bunyi bahasa, perbendaharaan kata dan struktur kalimat (Nababan,1993). Dalam mempelajari suatu bahasa yang sifatnya praktis, materi pelatihan berbahasa dominan pada pelatihan keterampilan berbahasa yaitu bagaimana bahasa itu dimanfaatkan dalam Keterampilan Berbicara (speaking), Keterampilan Menyimak (listening) yaitu kemampuan mengidentifikasi bunyi sehingga dapat memahami dan mengerti kosakata yang diucapkan oleh seseorang; Keterampilan Membaca (reading) yakni memahami dan mengerti pesan yang disampaikan oleh seseorang melalui teks tertulis dan dapat member respon yang tepat baik sifatnya perbuatan maupun sifatnya tulisan, Keterampilan Menulis (writing) yakni kemampuan seseorang menuliskan pesannya untuk disampaikan kepada pembaca atau partner berkomunikasi.

Dalam pendekatan Pengajaran Bahasa sebagaimana disampaikan oleh Davies dan Elder (2006) bahwa dalam merancang pembelajaran bahasa yang sifatnya praktis maka pembelajar harus diberi pengalaman nyata berupa cara mengucapkan bunyi-bunyi bahasa, kalimat dan menguasai sejumlah kosakata umum dan khusus dalam bidang tertentu. Dari proses latihan nyata tersebut akan tersimpan dalam pikiran pembelajar sejumlah sistem bahasa mulai dari bunyi hingga pada kalimat. Sejumlah sistem bahasa tersebut dapat dipakai dalam berkomunikasi secara nyata dalam komunikasi sehari-hari.

Berkenaan dengan pelatihan bahasa inggris, Larsen -Freeman (1996) mengemukakan pendekatan audio lingual method yang dikombinasikan dengan pendekatan komunikatif sebagaimana yang telah dikembangkan oleh Littlewood (1991). Kombinasi pendekatan ini dapat saja menjadi lebih efektif mencapai target pelatihan bahasa inggris yang sifatnya praktis. Pada pendekatan audio lingual method berfungsi membentuk kebiasaan atau habitual action melalui teknik pengulangan (drilling) yakni penekanan pada audio lingual yaitu latihan mengidentifikasi bunyi sampai pada pemahaman secara otomatis terhadap ucapan yang disampaikan. Keterampilan ini dapat terbentuk bunyi dan kosakata yang diperdengarkan berulang-ulang kemudian diikuti latihan (practice), pengucapan secara otomatis (pronounce), di samping itu kosakata dan kalimat dapat pula direkam dengan optimal dalam otak.

Lebih lanjut Littlewood (1991) menegaskan bahwa dalam belajar bahasa tidak lepas dari konteks dan situasi, kadang suatu tuturan atau ucapan (utterance) menimbulkan makna baru yang disebut dengan pragmatik. Konteks 
ini harus pula dipahami dan dimengerti oleh pembelajar bahasa. Untuk itu situasi dan konteks nyata harus pula menjadi bagian yang terpisahkan dengan pembelajaran bahasa. Disinilah fasilitator dituntut memiliki daya cipta guna merancang materi-materi yang sesuai dengan kebutuhan peserta. Pelatihan yang kreatif dan dapat mengantarkan peserta pelatihan agar mampu berkomunikasi dan berinteraksi. Berkenaan dengan tujuan pelatihan ini maka pendekatan kombinatif sangat tepat digunakan.

\section{METODE PELAKSANAAN}

Metode pelaksanaan pelatihan ini adalah berupa pengajaran intensif praktek dan latihan kepada peserta Kejar Paket C di Kelurahan Tanjung Karang, Kecamatan Sekarbela- Kota Mataram. Pelaksanaan kegiatan ini tidak berbeda jauh dengan tahap pelaksanaan kegiatan pembelajaran yang dilakukan sehari-hari pada Program Kejar Paket C. Perbedaannya adalah tentang metode dan media pembelajaran. Pengenalan bahasa inggris sebelumnya hanya melalui metode ceramah yang kurang melibatkan partisipasi peserta pelatihan. Pelaksanaan pelatihan ini menngunakan metode langsung sesuai dengan kebutuhan dan harapan peserta pelatihan.

Guna mengetahui kemampuan bahasa inggris awal peserta pelatihan dilakukan pre-test, setelah mengetahui kemampuan awal peserta pelatihan kemudian ditentukan materi-materi yang sesuai dengan kebutuhan dan kapasitas peserta pelatihan. Selanjutnya pelatihan dilaksanakan dalam empat kategori utama sesuai dengan empat keterampilan utama dalam bahasa inggris yaitu keterampilan membaca (reading), keterampilan berbicara (speaking), keterampilan menyimak (listening) dan Keterampilan menulis (writing). Pelatihan peningkatan keterampilan bahasa inggris praktis bagi peserta program Kejar Paket $\mathrm{C}$ dilaksanakan dalam 10 kali pertemuan dimana tiap pertemuan dilaksanakan selama 90 menit.

TABEL I

MATERI PELATIHAN

\begin{tabular}{|c|c|c|c|}
\hline No. & Topics & $M_{a}$ & Duaenis compeiency \\
\hline 1. & $\begin{array}{l}\text { Introduction } \\
\text { Greeting }\end{array}$ & $\begin{array}{l}\text { a. Introduce her/himself } \\
\text { b. Introduce friends/classmates } \\
\text { c. Greeting }\end{array}$ & $\begin{array}{l}\text { Trainees can } \\
\text { introduce him/herself } \\
\text { in front of the class } \\
\text { and do greetings. }\end{array}$ \\
\hline 2. & $\begin{array}{l}r t s \text { of the } \\
d y\end{array}$ & $\begin{array}{l}\text { in part of human body } \\
\text { tly } \\
\text { in the function of human } \\
\text { orrectly }\end{array}$ & $\begin{array}{l}\text { Trainees can explain } \\
\text { part and function of } \\
\text { human body correctly }\end{array}$ \\
\hline 3. & $\begin{array}{l}\text { Days, Months } \\
\text { Years }\end{array}$ & $\begin{array}{l}\text { a. Explain days, months and } \\
\text { years correctly } \\
\text { b. Write days, months and years } \\
\text { correctly }\end{array}$ & $\begin{array}{lr}\text { Trainees can explain } \\
\text { and writes } & \text { days, } \\
\text { months and } & \text { years } \\
\text { correctly } & \end{array}$ \\
\hline 4. & $\begin{array}{l}\text { Tenses } \\
\text { Simple Present } \\
\& \text { Past Tense }\end{array}$ & $\begin{array}{l}\text { a. Patterns for simple and past } \\
\text { tenses } \\
\text { b. Differentiate \& make examples } \\
\text { of simple - past tenses }\end{array}$ & $\begin{array}{l}\text { Trainees can } \\
\text { differentiater the } \\
\text { differentiation simple- } \\
\text { past tenses, makes } \\
\text { own examples. }\end{array}$ \\
\hline 5. & $\begin{array}{l}\text { Descriptive- } \\
\text { Argumentative } \\
\text { text }\end{array}$ & $\begin{array}{l}\text { axplain definition of } \\
\text { descriptive text } \\
\text { b. Explain definition of } \\
\text { argumentative text } \\
\text { c. Explain characteristics that }\end{array}$ & $\begin{array}{ll}\text { Trainees } & \text { can } \\
\text { differentiate } & \text { and } \\
\text { Writes descriptive } & \text { and } \\
\text { argumentative } & \text { text } \\
\text { correctly } & \end{array}$ \\
\hline
\end{tabular}




\begin{tabular}{|c|c|c|c|}
\hline No. & Topics & Materials & tency \\
\hline & & $\begin{array}{l}\text { differentiate descriptive and } \\
\text { argumentative text } \\
\text { d. Write argumentative and } \\
\text { descriptive text based on their } \\
\text { characteristics }\end{array}$ & \\
\hline 6. & $\begin{array}{l}\text { Nouns }^{-V_{\text {Verbs }}^{-}} \\
\text {Adjective }^{-} \\
\text {Adverbs }\end{array}$ & $\begin{array}{l}\text { a. Offering help and service } \\
\text { b. Responding request } \\
\text { c. Showing interesting } \\
\text { information }\end{array}$ & $\begin{array}{l}\text { Trainees can } \\
\text { differentiate nouns, } \\
\text { verbs, adverbs and } \\
\text { adjective correctly and } \\
\text { use in their daily } \\
\text { interaction }\end{array}$ \\
\hline 7. & $\begin{array}{l}\text { Cardinal- } \\
\text { Ordinal } \\
\text { Numbers }\end{array}$ & $\begin{array}{lll}\text { a. } & \text { Explain } & \text { cardinal-ordinal } \\
& \text { numbers } & \\
\text { b. } & \begin{array}{l}\text { Differentiate } \\
\text { numbers }\end{array} & \\
& \end{array}$ & $\begin{array}{l}\text { Trainees understand } \\
\text { cardinal-ordinal } \\
\text { numbers }\end{array}$ \\
\hline 8. & $\begin{array}{l}\text { Reading } \\
\text { Comprehension }\end{array}$ & $\begin{array}{l}\text { a. Developing vocabulary } \\
\text { b. Answering questions } \\
\text { c. Re-expressing reading content }\end{array}$ & $\begin{array}{l}\text { Trainees can } \\
\text { understand and } \\
\text { comprehend } \\
\text { vocabulary-message } \\
\text { behind text }\end{array}$ \\
\hline 9. & Speaking & 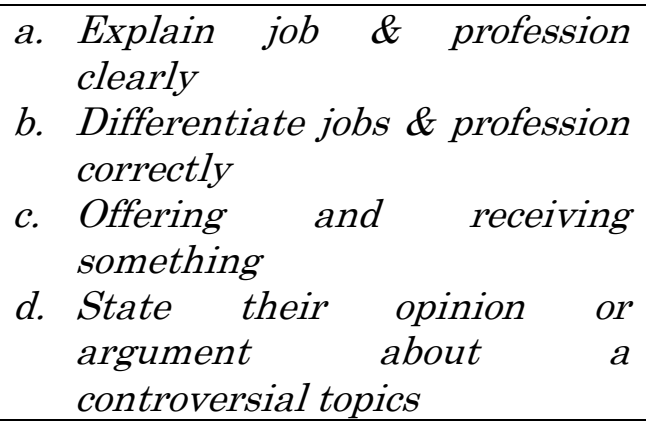 & $\begin{array}{l}\text { Trainees can explain } \\
\text { job \& profession, } \\
\text { offering and receiving } \\
\text { something, give their } \\
\text { opinion clearly and } \\
\text { correctly }\end{array}$ \\
\hline 10. & $\begin{array}{l}\text { Listening } \\
\text { exercise and } \\
\text { understanding } \\
\text { short discourse }\end{array}$ & $\begin{array}{l}\text { a. Developing listening } \\
\text { comprehension by answering } \\
\text { questions } \\
\text { b. Expressing the content of } \\
\text { passage } \\
\text { c. Find out message behind } \\
\text { discourse/conversation }\end{array}$ & $\begin{array}{l}\text { Trainees able to } \\
\text { understand simple } \\
\text { talk and discourse in } \\
\text { interaction. They can } \\
\text { find out the message } \\
\text { behind discourse or } \\
\text { conversation } \\
\text { correctly. }\end{array}$ \\
\hline
\end{tabular}

Pelatihan peningkatan keterampilan bahasa inggris praktis bagi peserta program kejar paket c diakhiri dengan pelaksanaan post test, post test dilakukan secara lisan dan tulisan (orally \& writtenly). Tujuan dilakukannya post test di akhir kegiatan adalah untuk mengetahui sejauh mana peserta mengalami peningkatan setelah mengikuti pelatihan.

\section{HASIL}

Kegiatan inti pelaksanaan pelatihan peningkatan keterampilan bahasa inggris praktis bagi peserta program kejar paket C di Kelurahan Tanjung Karang -Kota Mataram adalah sebagai berikut:

\section{Pertemuan I}

Pada pertemuan pertama, diberikan materi "Introduction \& Greetings" dengan menggunakan metode Grammar Translation, role play \& paper game. Media yang 
digunakan adalah papan tulis, LCD, spidol, buku LKS. Paper game adalah sebuah permainan yang menggunakan kertas sebagai bahan untuk membuat bola kecil, setelah itu bola diberikan dari satu peserta kepada peserta lainnya disertai nyanyian bahasa inggris berjudul Alphabet. Metode ini digunakan agar peserta dapat lebih mudah menghafal alphabet sedangkan game digunakan untuk menarik minat peserta untuk belajar bahasa inggris. Bagi peserta yang memegang bola kertas saat lagu berakhir, maka peserta tersebut harus memperkenalkan dirinya dihadapan peserta-peserta lain. Peserta pelatihan berjumlah 25 orang, berdasarkan game yang diberikan diketahui bahwa terdapat 6 peserta pelatihan yang memiliki kemampuan sangat baik, 12 orang memiliki kemampuan rata-rata dan 7 orang peserta memiliki kemampuan yang masih rendah.

\section{Pertemuan II}

Pada pertemuan kedua digunakan metode contextual teaching learning untuk materi "Part of the body". Penggunaan metode contextual learning (CTL) dianggap mampu meningkatkan kemampuan kemampuan siswa melalui pemberian materi-materi yang dapat diterapkan secara langsung dalam kelas. Terdapat 5 orang peserta yang dapat menyebutkan bagian-bagian tubuh manusia dengan benar, 8 orang peserta yang yang berada dalam kategori rata-rata dan 5 peserta sudah mampu menyebutkan bagian tubuh manusia namun belum mampu mengucapkannya dengan benar dalam bahasa inggris.

\section{Pertemuan III}

Penyampaian materi dengan metode Grammar Translation, role play and boom game. Untuk menarik minat belajar dan meningkatkan motivasi peserta digunakan permainan "boom game", permainan ini merupakan permainan tebak tebakan guna menebak hari, bulan dan tahun dalam bahasa inggris. Berdasarkan game yang diberikan dapat diketahui terdapat 4 orang peserta yang memiliki kemampuan sangat baik, 8 peserta memiliki kemampuan rata-rata dan 7 peserta memiliki kemampuan yang masih rendah.

\section{Pertemuan IV}

Metode yang digunakan Grammar Translation Method dengan diselingi permainan yaitu Whisper Game, permainan ini melatih kemampuan panca indera pendengaran sebagai alat utama dalam permainan ini. Peserta pelatihan dibagi menjadi tiga kelompok kemudian diberi satu kalimat sebagai kata kunci terkait topic. Pada hitungan ketiga, tiap-tiap peserta harus memperagakan sesuai kalimatnya. Pertemuan keempat ini diikuti oleh 18 peserta, diakhir pembelajaran diketahui bahwa terdapat 10 peserta memiliki kemampuan yang baik, 5 peserta memiliki kemampuan rata-rata dan 3 peserta memiki kemampuan masih rendah.

\section{Pertemuan V}

Metode yang digunakan pada pertemuan kelima adalah contextual teaching, selain itu media yang digunakan adalah papan tulis. Permainan yang diterapkan adalah "Guessing" yaitu permainan guna melatih peserta mengidentifikasi, memahami dan membedakan kata benda (nouns), kata kerja (verbs), kata sifat (adjectives) dan kata keterangan (adverbs). Pertemuan kelima diikuti oleh 20 peserta, diakhir pembelajaran diketahui bahwa terdapat 12 peserta memiliki kemampuan yang baik, 6 peserta memiliki kemampuan rata-rata dan 2 peserta memiki kemampuan masih rendah. 


\section{Pertemuan VI}

Pertemuan keenam menggunakan metode ceramah yang dilanjutkan dengan diskusi serta Tanya jawab. Selanjutnya diselingi dengan permainan "whispering game" guna meningkatkan kemampuan kosakata peserta pelatihan. Pertemuan keenam diikuti oleh 25 peserta, diakhir pembelajaran diketahui bahwa terdapat 13 peserta memiliki kemampuan baik, 5 peserta memiliki kemampuan rata-rata, dan 7 peserta memiliki kemampuan masih rendah.

\section{Pertemuan VII}

Pada pertemuan ketujuh digunakan diskusi kelompok guna membahas suatun topik yang kontroversial. Selanjutnya setelah sesi Tanya jawab berakhir dilanjutkan dengan permainan yaitu "boom game", permainan ini melatih hpeserta pelatihan terkait kosakata yang berkaitan dengan materi diskusi. Kemampuan yang diperoleh peserta adalah kemampuan menguasai dan memahami urutan bilangan dalam bahasa inggris. Pertemuan ketujuh diikuti oleh 22 peserta, diakhir pembelajaran diketahui bahwa terdapat 10 peserta memiliki kemampuan baik, 3 peserta memiliki kemampuan rata-rata, dan 7 peserta memiliki kemampuan masih rendah.

\section{Pertemuan VIII}

Pertemuan kedelapan diikuti oleh 22 peserta, metode yang digunakan adalah audio lingual method dengan diselingi permainan yaitu "role play", permainan ini ditujukan untuk meningkatkan kemampuan berbicara (speaking), kemampuan menyimak (listening) serta memperkaya kosakata (vocabulary). Diakhir pembelajaran, diketahui bahwa terdapat 5 peserta yang memiliki kemampuan baik, 13 peserta memiliki kemampuan rata-rata dan 4 peserta memiliki kemampuan masih rendah.

\section{Pertemuan IX}

Pertemuan kesembilan diikuti oleh 18 peserta, metode yang digunakan adalah grammar translation method dengan teknik brainstorming, kegiatan-kegiatan tersebut guna meningkatkan kemampuan berbicara (speaking), menulis (writing), menyimak (listening), membaca (reading) serta kosakata (vocabulary). Diakhir pembelajaran diketahui bahwa terdapat 8 peserta memiliki kemampuan baik, 5 peserta memiliki kemampuan rata-rata dan 5 peserta memiliki kemampuan masih rendah.

\section{Pertemuan X}

Metode yang digunakan adalah group discussion, peserta dibagi menjadi 4 kelompok dimana masing-masing kelompok mempresentasikan tentang karangan argumentasi sesuai topic yang telah ditentukan, selanjutnya dilanjutkan dengan sesi tanya jawab. Pembelajaran diselingi dengan permainan yaitu sticky game. Pertemuan kesepuluh diikuti oleh 25 peserta dimana diakhir pembelajaran diketahui bahwa terdapat 16 peserta memiliki kemampuan baik, 5 peserta memiliki kemampuan rata-rata dan 4 peserta memiliki kemampuan masih rendah.

\section{E. PEMBAHASAN}

Berdasarkan hasil pelaksanaan pelatihan peningkatan keterampilan berbahasa inggris praktis bagi peserta Program Kejar Paket C di lingkungan kekalik jaya, terlihat adanya peningkatan baik dari segi motivasi peserta maupun tingkat kemampuan berbahasa peserta. Penilaian atau evaluasi dilakukan secara kualitatif yang dibagi menjadi 3 kategori yaitu kategori baik, sedang dan rendah. Evaluasi dilakukan dengan mengkaji bagaimana respon, motivasi dan kedisiplinan peserta 
serta kelancaran penerimaan materi guna mengukur tingkat keberhasilan kegiatan ini.

Keberhasilan pelaksanaan kegiatan di evaluasi dari dua dimensi yaitu dimensi output dimana pengukuran berdasarkan penyajian materi telah tercapai dengan target ideal $80 \%$, penguasaan atau penyerapan materi yang dicapai oleh peserta $75 \%$ dan aspek keterampilan berbahasa inggris dengan target ideal $75 \%$. Selanjutnya dari dimensi outcomes, di evaluasi dari kemampuan peserta menguasai bahasa inggris secara lisan dan tulisan dengan target ideal $75 \%$, daya serap peserta $75 \%$. Selanjutnya dari hasil capaian kegiatan diatas, dapat dijelaskan bahwa terjadi peningkatan motivasi dan partisipasi peserta serta peningkatan skor pencapaian pada test akhir (post test) jika dibandingkan dengan test awal (pre test).

\section{F. TEMUAN \& DISKUSI}

Dari data hasil capaian kegiatan di atas, dapat dijelaskan bahwa dari sisi dimensi output tampak bahwa motivasi dan partisipasi peserta serta pemerintah meningkat signifikan dalam meningkatkan keterampilan berbahasa peserta. Penguasaan materi mencapai $75 \%$, adapun kemampuan berbahasa yang terdiri dari keterampilan berbicara (speaking), keterampilan menyimak (listening), keterampilan membaca (reading) dan keterampilan menulis (writing) dapat dicapai $60 \%$ dari target ideal yang diharapkan. Kemampuan mensimulasikan peran sebagai bentuk peningkatan kosakata mencapai target ideal yaitu $80 \%$.

Ditinjau dari dimensi outcomes, terdapat beberapa faktor yang mencapai target yaitu inisiatif atau keberanian berbicara dengan bahasa inggris mencapai $70 \mathrm{~b} \%$ dari target ideal dan kemampuan menulis mencapai $75 \%$ dari target ideal. Berdasarkan hasil temuan tersebut, pelatihan peningkatan kemampuan bahasa inggris telah menunjukkan adanya peningkatan meskipun belum dapat mencapai target ideal.

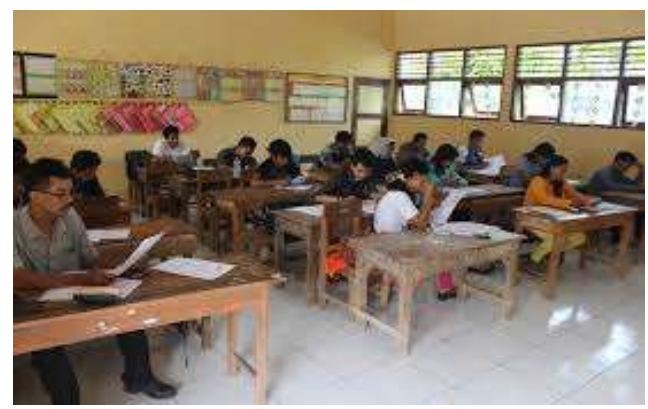

Gambar 1. Suasana Pelatihan Bahasa Inggris Peserta Kejar Paket C ( Pertemuan Pertama)

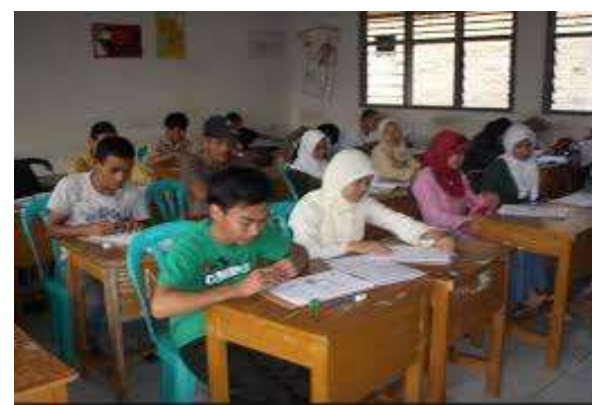

Gambar 2. Suasana Pelatihan Bahasa Inggris Peserta Kejar Paket C ( Pertemuan Kedelapan )

\section{G. SIMPULAN \& SARAN}

\section{Simpulan}

Dalam upaya peningkatan kualitas sumber daya manusia, penguasaan bahasa asing khususnya bahasa inggris merupakan hal yang sangat penting. Pelatihan peningkatan kemampuan berbahasa inggris merupakan salah satu upaya untuk membekali peserta program kejar paket $\mathrm{C}$ dengan kemampuan berbahasa inggris sehingga dapat meningkatkan peluang mereka memperoleh pekerjaan.

Berdasarkan paparan hasil kegiatan dan pembahasan maka dapat disimpulkan beberapa hal yaitu penggunaan bahasa inggris setelah terlaksananya pelatihan peningkatan keterampilan bahasa inggris menunjukkan adanya peningkatan yang cukup signifikan. Para peserta pelatihan menjadi 
termotivasi untuk meningkatkan keterampilan bahasa inggris mereka yang dapat menjadi nilai tambah saat mereka mencari kerja. Selain peningkatan motivasi, terlihat pula adanya peningkatan skor capaian peserta dari hasil test awal hingga test akhir.

2. Saran

Berdasarkan kesimpulan di atas diberikan saran-saran sebagai berikut:

a. Mengingat besarnya manfaat yang diperoleh dari pelatihan ini maka kegiatan-kegiatan serupa perlu terus diselenggarakan secara intensif dengan terus memperkaya variasi metode, strategi dan teknik pembelajaran.

b. Perlu ditingkatkan kerjasama kolaboratif antara penyelenggara program kejar paket dengan para praktisi pendidikan guna meningkatkan dan mengembangkan potensi sumber daya manusia.

\section{UCAPAN TERIMA KASIH}

Penulis mengucapkan terima kasih yang sebesar-besarnya kepada Bapak Lurah Tanjung Karang, Kepala Lingkungan Kekalik Jaya, Panitia Penyelenggara Program Kejar Paket C serta Lembaga Pengabdian Pada Masyarakat (LPPM) Universitas Muhammadiyah Mataram, atas dukungan dan kerjasamanya sehingga kegiatan pengabdian masyarakat ini dapat terselenggara dengan baik dan sesuai harapan.

\section{DAFTAR RUJUKAN}

Achmad, S. 2011. Workshop Pengembangan Karakter di SMP Negeri 2 Limboto, Gorontalo. Gorontalo: LPMP Gorontalo.

Nababan, 1993. Sosiolinguistik: Suatu Pengantar. Jakarta: PT. Gramedia.

Djojosuroto, Kinayanti. 2007. Pengajaran Bahasa Inggris. Jakarta: LIPI

Emmer, Edman T. 1993. Classroom Management for Secondary \& Elementary, Second Edition. New Jersey: Eaglewood Cliff Press.

Mahsun, 2005. Metode Penelitian Bahasa: Tahapan, Strategi, Metode dan tekniknya. Jakarta: PT.Grasindo Perkasa.

Cohen, Elizabeth. 1986. Designing Groupwork: Strategies for the Heterogenous Classroom. London: Columbia University Press.

Peraturan Menteri Pendidikan Nasional No 23 Tahun 2006 tentang Standar Kompetensi Lulusan. 